\title{
Detection of antibiotic resistance genes in wastewater treatment plant - molecular and classical approach
}

\author{
Aleksandra Ziembińska-Buczyńska*, Ewa Felis, Justyna Folkert, Anna Meresta, \\ Dominika Stawicka, Anna Gnida, Joanna Surmacz-Górska \\ The Silesian University of Technology, Poland \\ The Faculty of Environmental Engineering and Energy \\ Environmental Biotechnology Department \\ *Corresponding author's e-mail: aleksandra.ziembinska-buczynska@polsı.pl
}

\begin{abstract}
Keywords: DGGE, PCR, sulfamethoxazole, trimethoprim and erythromycin resistance, WWTP.
\end{abstract}
\begin{abstract}
Antibiotics are a group of substances potentially harmful to the environment. They can play a role in bacterial resistance transfer among pathogenic and non-pathogenic bacteria. In this experiment three representatives of medically important chemotherapeutics, confirmed to be present in high concentrations in wastewater treatment plants with HPLC analysis were used: erythromycin, sulfamethoxazole and trimethoprim. Erythromycin concentration in activated sludge was not higher than $20 \mathrm{ng} \mathrm{L}^{-1}$. N-acetylo-sulfamethoxazole concentration was $3349 \pm 719$ in winter and $2933 \pm 429 \mathrm{ng} \mathrm{L}^{-1}$ in summer. Trimethoprim was present in wastewater at concentrations $400 \pm 22$ and $364 \pm 60 \mathrm{ng} \mathrm{L}^{-1}$, respectively in winter and summer. Due to a wide variety of PCR-detectable resistance mechanisms towards these substances, the most common found in literature was chosen. For erythromycin: erm and mef genes, for sulfamethoxazole: sull, sul2, sul3 genes, in the case of trimethoprim resistance $\operatorname{dhfrAl}$ and $d h f r 14$ were used in this study. The presence of resistance genes were analyzed in pure strains isolated from activated sludge and in the activated sludge sample itself. The research revealed that the value of minimal inhibitory concentration (MIC) did not correspond with the expected presence of more than one resistance mechanisms. Most of the isolates possessed only one of the genes responsible for a particular chemotherapeutic resistance. It was confirmed that it is possible to monitor the presence of resistance genes directly in activated sludge using PCR. Due to the limited isolates number used in the experiment these results should be regarded as preliminary.
\end{abstract}

\section{Introduction}

Pharmaceuticals, including antibiotics, are an important and diverse group of substances potentially harmful to the environment. They are necessary in bacterial disease treatment but their inappropriate or overusage can cause bacterial resistance (Wise 2002). Interestingly, not the hospitals but single households are the main source of antibiotics in the environment. It was estimated that antibiotics worldwide consumption is ca. $0.1-0.2 \mathrm{Mt} \mathrm{yr}^{-1}$ (Wise, 2002). To this, there is use of them in aquaculture, bee-keeping and fruit-farming (Kümmerer 2009). In their "lifecycle" antibiotics and/or their metabolites are directed to the wastewater treatment plants and then to water and further to the other parts of the environment.

Antibiotics resistance is a timely topic due to the possibility of its transfer among pathogenic and non-pathogenic bacteria (Rahube and Yost 2010). This phenomenon is possible because the resistance genes are often located on mobile genetic elements, such as plasmids, which appear commonly in bacteria-rich areas such as wastewater treatment plants (WWTPs). From WWTPs they are directed to the water tracts becoming a danger for public health. The monitoring of antibiotic resistance presence and transfer in activated sludge seems to be reasonable part of the antibiotics usage politics. These analyses can be performed with traditional cultivation methods but more often than not, the molecular approach based on PCR (polymerase chain reaction) is used due to the higher sensitivity and precision of the test. More than $95 \%$ of the environmental bacteria cannot be cultivated in the laboratory (Oliver 2010). That is the other reason why traditional microbiological methods should be supported with molecular tools.

In this experiment three representatives of medically important chemotherapeutics and antibiotics confirmed to be present in high concentrations in WWTPs: erythromycin, sulfamethoxazole and trimethoprim were chosen. These substances are very popular in Poland for bacterial diseases treatment and their concentration in wastewater is high especially during autumn-winter season.

Erythromycin is a macrolide antibiotic that has an antimicrobial spectrum slightly wider than that of penicillin and used more often in bacterial infection treatment. Microorganisms possess several resistance mechanisms towards erythromycin, 
such as a modification of the antibiotic-ribosome binding place by methylation/mutation or active erythromycin removal from bacterial cell by transporting proteins located in cell membrane or enzymatic inactivation (Weisblum 1995). The genetic control of the erythromycin resistance is based both on chromosomal and plasmid-coded information. Methylases are encoded by plasmid-located erm genes. These genes determine multiresistance towards macrolides, lincosamides and streptogramins B. They are spread among Gram-positive and Gram-negative bacteria. Chromosomal or plasmid-located mef and $m s r$ genes encode active erythromycin efflux (Matsuoka et al. 2003). Mef proteins appear mainly among Gram-positive bacteria. These genes are easily transferable among genus and species. The most common resistance mechanisms are binding site modification and active antibiotic removal, that is why in this experiment erm and mef genes were chosen to monitor erythromycin resistance in activated sludge.

Sulfamethoxazole is a sulfonamide antibiotic in which bactericidal efficacy increases in combination with trimethoprim - a bacteriostatic chemotherapeutic agents known as dihydrofolate reductase inhibitor (DHPS) (Huovinen 2001). Because these two drugs are used as a combination with synergic effect their resistance mechanisms when separately analyzed are difficult to distinguish. The most reasonable theory as to how bacteria gain resistance towards the combination of these two drugs is probably through the permeability barrier and/or efflux pumps (Huovinen 2001). Sulphonamides resistance is probably encoded with plasmid-located sul genes. Two types of this gene - sull and sul2, are commonly present in Gram-negative bacteria and they are detected in resistant microorganisms in comparable frequency (Sköld 2001, Perreten and Boerlin 2003). Sul1 and sul2 are similar to each other in $57 \%$, but their origin is still unknown. In 2003 sul3 gene presence in E. coli strain isolated from pigs in Switzerland was reported (Perreten and Boerlin 2003).

Trimethoprim resistance is mainly based on modified dihydrofolate reductase production encoded by dhfr genes. We actually know 30 types of $d h f r$ gene, linked with integrons, transposons and plasmids (Brolund et al. 2010). The most common in Gram-negative bacteria is $\operatorname{dhfrA1}$, appearing in the integron cassettes class 1 and 2, which could be located on plasmid or chromosome (Sköld 2001).

The aim of this study was to assess the possibility of fast PCR detection of resistance genes towards erythromycin, sulfamethoxazole and trimethoprim in both activated sludge and pure strains isolated from a communal wastewater treatment plant in Zabrze (Poland). Resistant bacteria were also enumerated with the microbiological plating method. Activated sludge samples collected in four seasons within one year underwent PCR-DGGE (polymerase chain reaction-denaturing gel electrophoresis) analysis to estimate the genetic changeability of the biocenosis. HPLC (high pressure liquid chromatography) was used to detect the antibiotic concentrations chosen for the experiment.

\section{Materials and methods}

\section{HPLC - based determination of the antimicrobial agents presence in the wastewater treatment plant}

The presence of antimicrobial agents in the wastewater treatment plant was determined by means of HPLC method combined with MS detection in the influent and the effluent of the WWTP. The samples (volume of $1 \mathrm{~L}$ ) were collected three times per season from bioreactor and from return sludge containers. These locations were chosen as a potential reservoir of antimicrobial agents and resistance genes. The samples were frozen and stored in dark-glass bottles at $-20^{\circ} \mathrm{C}$ until analysis. After defrosting, samples were filtered through glass fiber filters (pore size of $<1 \mu \mathrm{m}$, diameter $55 \mathrm{~mm}$; Dassel, Germany). One hundred $\mathrm{mL}$ of the influent and $200 \mathrm{~mL}$ of the effluent were spiked with a mixture of internal standards (IS). The $\mathrm{pH}$ of all samples was adjusted to 7.5. As the internal standards the following substances were used: sulfamerazine-d4 (IS for sulfonamides and trimethoprim), sulfamethoxazole-d4 (IS for sulfamethoxazole; Sigma-Aldrich), N-acetyl-sulfamethoxazole-d5 (IS for N-acetyl-sulfamethoxazole; Sigma-Aldrich) and (E)-9-[O-(2methyloxime)]-erythromycin (IS for macrolides; synthesized according to the procedure described previously (Schluesener et al. 2003). The solid phase extraction of the wastewater samples was performed using Oasis HLB (200 mg, $6 \mathrm{~mL}$ ) cartridges (Waters, Milford, MA, USA). Conditioning and drying of the cartridges were performed as previously described (Hjosa-Valsero et al. 2011). The analytes were eluted with $4 \times 2 \mathrm{~mL}$ acetone. The eluates were concentrated to the volume of $200 \mu \mathrm{L}$, diluted with $250 \mu \mathrm{L}$ of methanol and evaporated under a gentle nitrogen stream to the volume of $100 \mu \mathrm{L}$. Then the extracts were redissolved in $400 \mu \mathrm{L}$ Milli-Q water. All the samples were analyzed by reversed-phase liquid chromatography-tandem mass spectrometry (HPLC-MS-MS). The HPLC system consisted of a G1313A autosampler, a G1311A quaternary HPLC pump, a G1379A degasser (all Agilent, Waldbronn, Germany), a CTO-10A column oven and a SCL-10A system controller (all Shimadzu, Duisburg, Germany). More details concerning chromatographic analysis performance are presented in (Hjosa-Valsero et al. 2011).

\section{Enumeration and isolation of antibiotic resistant bacteria in activated sludge}

Activated sludge samples were collected from municipal WWTP in Zabrze (Poland) three times per sampling time from bioreactor and return sludge container. The samples were diluted in sterile $0.9 \% \mathrm{NaCl}$ to $10^{-12}$ and the suspension was used to inoculate agar plates containing Mueller-Hinton medium (BTL, Poland) with sulfamethoxazole, trimethoprim and erythromycin in concentration of $5 \mu \mathrm{g} \mathrm{mL}^{-1}$ each (Polfarma, Poland). Mueller-Hinton plates without antibiotics were used as a control. The plates in triplicate from each dilution were incubated for $24-48 \mathrm{~h}$ in $20 \pm 1^{\circ} \mathrm{C}$. Bacteria growing on particular antibiotic plates and on the control plates were counted and several morphological bacteria types were selected for pure strain isolation. The isolated strains underwent morphological identification with Gram staining.

\section{Minimal Inhibitory Concentration (MIC) value estimations for isolated bacteria}

The estimations of MIC of antibiotics used in the experiment: erythromycin, sulfamethoxazole and trimethoprim were performed in liquid broth medium (BTL, Poland) with antibiotics in concentration of: $4-1024 \mu \mathrm{g} \mathrm{mL}-1$ (Martin et 
al. 2001). The $24 \mathrm{~h}$ colonies of the isolates were analyzed for MIC value in triplicate. The samples were incubated for $24 \mathrm{~h}$ in $26^{\circ} \mathrm{C}$.

\section{DNA extraction and PCR conditions for activated sludge samples prepared for DGGE}

Activated sludge samples (volume of $10 \mathrm{~mL}$ ) Zabrze WWTP were pelleted by centrifugation $\left(10000 \mathrm{rpm}, 10 \mathrm{~min}, 4^{\circ} \mathrm{C}\right)$ and stored at $-20^{\circ} \mathrm{C}$. Total genomic DNA was extracted from $0.2 \mathrm{~g}$ of the activated sludge samples with mechanical method. The samples washed with $1 \times$ PBS buffer (Sigma) were disintegrated with bead beating (Roth, Germany) in lysis buffer containing Tris-HCl $100 \mathrm{mM}$, EDTA $100 \mathrm{mM}$ and $\mathrm{NaCl} 1.5 \mathrm{M}$ $(\mathrm{pH}=8.0)$. The samples were incubated $20 \mathrm{~min}$ in $1400 \mathrm{rpm}$ and $200 \mu \mathrm{L} 10 \%$ SDS was added. After $30 \mathrm{~min}$ of incubation in $65^{\circ} \mathrm{C}$ samples were centrifuged twice at $13000 \mathrm{rpm}$ and placed on spin filters (A\&A Biotechnology). DNA attached to the filter was washed twice with $70 \%$ ethanol solution (A\&A Biotechnology). The amount of DNA was measured spectrophotometrically using Qubit (Invitrogen) and stored at $-20^{\circ} \mathrm{C}$ until PCR amplification.

In this study partial $16 \mathrm{~S}$ rRNA gene amplification was performed using primers $338 \mathrm{~F}$ with GC clamp and $518 \mathrm{R}$, which amplified a partial (ca. $180 \mathrm{bp}$ ) 16S rRNA gene fragment of all the bacteria (Muyzer et al. 1993). PCR procedure was described previously (Ziembińska et al. 2009).

\section{Denaturing gradient gel electrophoresis conditions and results analysis}

The DGGE of the PCR products obtained in reactions with $338 \mathrm{~F}-\mathrm{GC}$ and 518R primers underwent electrophoretic separation in the Dcode Universal Mutation Detection System (BioRad). Polyacrylamide gel (8\% for $16 \mathrm{~S}$ rRNA gene, $37: 1$ acrylamide-bisacrylamide, Fluka) with a gradient of $30-60 \%$ denaturant was prepared according to the manufacturer's instruction. The gel was run for $10 \mathrm{~h}$ at $70 \mathrm{~V}$ in a $1 \times \mathrm{TAE}$ buffer (Tris, acetic acid, EDTA, $\mathrm{pH}=8.0$ ) at a constant temperature of $60^{\circ} \mathrm{C}$. The gel was stained with SYBR Gold (1:10 000, Invitrogen) in MiliQ water for $30 \mathrm{~min}$ and distained in MiliQ water for $40 \mathrm{~min}$, then visualized under UV light and photographed using Quantity One 1D (BioRad).

The analysis of DGGE fingerprints was performed using a Quantity One 1D software (BioRad). Bacterial biodiversity was estimated on the basis of densitometric measurements and Shannon diversity index was calculated (Ziembińska et al. 2009).

\section{DNA extraction form pure strains of antibiotic resistant bacteria isolated from activated sludge and PCR conditions for resistance genes identification}

DNA from resistant isolates to erythromycin and sulfametoxazole/trimethoprim were extracted using DNA Genomic Mini Kit (A\&A Biotechnology). The amount of DNA was measured spectrophotometrically using Qubit (Invitrogen) and stored at $-20^{\circ} \mathrm{C}$ until PCR amplification. PCR mixture volume of $30 \mu \mathrm{L}$ was containing: $1 \times$ polymerase buffer (Promega), $2 \mathrm{mM} \mathrm{MgCl}_{2}$ (Promega), 5 pmol dNTPs (Promega), 20 pmol of each primer (Genomed), 1.5 U GoTAQ Flexi Polymerase (Promega) and $0.15-0.2 \mu \mathrm{g} \mu \mathrm{L}^{-1}$ DNA. The DNA samples from resistant bacterial pure strains and total bacterial DNA from activated sludge were used as the templates.

The primers used in the study were targeting erm and mef genes responsible for erythromycin resistance, sull, sul 2 and sul 3 genes encoding sulfametoxazole resistance, and dhfrAl and dhfrAl4 genes used to detect trimethoprim resistance. Primers sequences and PCR amplification conditions are enlisted in Table 1 and 2, respectively. The products after PCR amplification were separated in $0.8 \%(\mathrm{w} / \mathrm{v})$ agarose gel (Promega) in $1 \times$ TBE buffer (Tris, boric acid, EDTA, $\mathrm{pH}=8.3$ ) with ethidium bromide (10 $\mathrm{mg} \mathrm{mL}^{-1}$; Promega), visualized under UV light and photographed.

\section{Results}

\section{HPLC analysis of antibiotics concentration}

HPLC analysis of raw and treated wastewater from Zabrze WWTP enabled the estimation of the concentration and

Table 1. Primers used in the study

\begin{tabular}{|c|c|c|}
\hline Primer & Primer's sequence 5'-3' & References \\
\hline ermF & 5' GAAAGGTACTCAACCAAATA 3' & \multirow{4}{*}{ Sutcliffe et al. 1996} \\
\hline ermR & 5' AGTAACGGTACTTAAATTGTTTAC 3' & \\
\hline mefF & 5' AGTATCATTAATCACTAGTGC 3' & \\
\hline mefR & 5' TTCTTCTGGTACTAAAAGTGG 3' & \\
\hline sul1F & 5’ ATGGTGGACGGTGTTCGGCATTCTGA 3' & \multirow{4}{*}{ Toleman et al. 2007} \\
\hline sul1R & 5' CTAGGCATGATCTAAACCCTCG 3' & \\
\hline sul2F & 5' GAATAAATCGCTCATCATTTTCGG 3' & \\
\hline sul2R & 5' CGAATTCTTGCGGTTTCAGC 3' & \\
\hline sul3F & 5' GAGCAAGATTTTTTGGAATCG 3' & \multirow{2}{*}{ Grape et al. 2003} \\
\hline sul3R & 5' CATCTGCAGCTAACCTAGGGCTTTGGA 3' & \\
\hline dhfrA1F & 5' CCAAAGGTGAACAGCTCCTG 3' & \multirow{4}{*}{ Hoek et al. 2005} \\
\hline dhfrA1R & 5' ATATGTAGTGTATCTACTTG 3' & \\
\hline dhfrA14F & 5' TCTGGTGGGTCGCAAAGACG 3' & \\
\hline dhfrA14R & 5' ATGGGTAATGTTTCTCGG 3' & \\
\hline
\end{tabular}


Table 2. PCR amplification programs used in the study

\begin{tabular}{|c|c|c|c|c|c|c|c|c|c|c|c|c|c|c|}
\hline $\begin{array}{ll} & \text { Primers } \\
\text { SCR } \\
\text { step }\end{array}$ & \multicolumn{2}{|c|}{ erm } & \multicolumn{2}{|c|}{ mef } & \multicolumn{2}{|c|}{ dhfrA1 } & \multicolumn{2}{|c|}{ dhfrA14 } & \multicolumn{2}{|c|}{ sul1 } & \multicolumn{2}{|c|}{ sul2 } & \multicolumn{2}{|c|}{ sul3 } \\
\hline $\begin{array}{l}\text { Pre- } \\
\text { denaturation }\end{array}$ & \multicolumn{2}{|c|}{$93^{\circ} \mathrm{C} / 3 \mathrm{~min}$} & \multicolumn{2}{|c|}{$93^{\circ} \mathrm{C} / 3 \mathrm{~min}$} & \multicolumn{2}{|c|}{$95^{\circ} \mathrm{C} / 3 \mathrm{~min}$} & \multicolumn{2}{|c|}{$95^{\circ} \mathrm{C} / 3 \mathrm{~min}$} & \multicolumn{2}{|c|}{$95^{\circ} \mathrm{C} / 5 \mathrm{~min}$} & \multicolumn{2}{|c|}{$95^{\circ} \mathrm{C} / 5 \mathrm{~min}$} & \multicolumn{2}{|c|}{$95^{\circ} \mathrm{C} / 5 \mathrm{~min}$} \\
\hline Denaturation & $\begin{array}{l}93^{\circ} \mathrm{Cl} \\
1 \mathrm{~min}\end{array}$ & \multirow{3}{*}{$\times 35$} & $\begin{array}{l}93^{\circ} \mathrm{Cl} \\
1 \mathrm{~min}\end{array}$ & \multirow{3}{*}{$\begin{array}{l}93^{\circ} \mathrm{C} / \\
1 \mathrm{~min} \\
52^{\circ} \mathrm{C} / \\
1 \mathrm{~min} \\
72^{\circ} \mathrm{C} / \\
1 \mathrm{~min}\end{array}$} & $\begin{array}{c}95^{\circ} \mathrm{C} / \\
30 \mathrm{sec}\end{array}$ & \multirow{3}{*}{$\times 35$} & $\begin{array}{c}95^{\circ} \mathrm{C} / \\
30 \mathrm{sec}\end{array}$ & \multirow{3}{*}{$\times 35$} & $\begin{array}{l}95^{\circ} \mathrm{C} / \\
15 \mathrm{sec}\end{array}$ & \multirow{3}{*}{$\times 30$} & $\begin{array}{l}95^{\circ} \mathrm{C} / \\
15 \mathrm{sec}\end{array}$ & \multirow{3}{*}{$\times 30$} & $\begin{array}{l}95^{\circ} \mathrm{C} / \\
15 \mathrm{sec}\end{array}$ & \multirow{3}{*}{$\times 30$} \\
\hline Annealing & $\begin{array}{l}52^{\circ} \mathrm{C} / \\
1 \mathrm{~min}\end{array}$ & & $\begin{array}{l}52^{\circ} \mathrm{Cl} \\
1 \mathrm{~min}\end{array}$ & & $\begin{array}{c}55^{\circ} \mathrm{C} / \\
30 \mathrm{sec}\end{array}$ & & $\begin{array}{c}55^{\circ} \mathrm{Cl} \\
30 \mathrm{sec}\end{array}$ & & $\begin{array}{c}51^{\circ} \mathrm{C} / \\
30 \mathrm{sec}\end{array}$ & & $\begin{array}{l}51^{\circ} \mathrm{C} / \\
30 \mathrm{sec}\end{array}$ & & $\begin{array}{l}51^{\circ} \mathrm{C} / \\
30 \mathrm{sec}\end{array}$ & \\
\hline Elongation & $\begin{array}{l}72^{\circ} \mathrm{Cl} \\
1 \mathrm{~min}\end{array}$ & & $\begin{array}{l}72^{\circ} \mathrm{Cl} \\
1 \mathrm{~min}\end{array}$ & & $\begin{array}{c}72^{\circ} \mathrm{C} / \\
30 \mathrm{sec}\end{array}$ & & $\begin{array}{c}72^{\circ} \mathrm{C} / \\
30 \mathrm{sec}\end{array}$ & & $\begin{array}{l}72^{\circ} \mathrm{Cl} \\
1 \mathrm{~min}\end{array}$ & & $\begin{array}{l}72^{\circ} \mathrm{Cl} \\
1 \mathrm{~min}\end{array}$ & & $\begin{array}{l}72^{\circ} \mathrm{Cl} \\
1 \mathrm{~min}\end{array}$ & \\
\hline $\begin{array}{l}\text { Final } \\
\text { elongation }\end{array}$ & \multicolumn{2}{|c|}{$72^{\circ} \mathrm{C} / 5 \mathrm{~min}$} & \multicolumn{2}{|c|}{$72^{\circ} \mathrm{C} / 5 \mathrm{~min}$} & \multicolumn{2}{|c|}{$72^{\circ} \mathrm{C} / 10 \mathrm{~min}$} & \multicolumn{2}{|c|}{$72^{\circ} \mathrm{C} / 10 \mathrm{~min}$} & \multicolumn{2}{|c|}{$72^{\circ} \mathrm{C} / 7 \mathrm{~min}$} & \multicolumn{2}{|c|}{$72^{\circ} \mathrm{C} / 7 \mathrm{~min}$} & \multicolumn{2}{|c|}{$72^{\circ} \mathrm{C} / 7 \mathrm{~min}$} \\
\hline References & \multicolumn{4}{|c|}{ Sutcliffe et al. 1996} & \multicolumn{4}{|c|}{ Hoek et al. 2005} & \multicolumn{6}{|c|}{ Hoa et al. 2008 , Hoek et al. 2005} \\
\hline
\end{tabular}

the removal percentage of the antibiotics used in the experiment. These values were calculated for erythromycin, sulfamethoxazole, N-acetylosulfamethoxazole (the main sulfamethoxazole metabolite) and trimethoprim for winter $\left(\mathrm{T}=10^{\circ} \mathrm{C}\right)$ and summer $\left(\mathrm{T}=20^{\circ} \mathrm{C}\right)$ sampling period (temperature measured in the nitrification chamber of WWTP). Erythromycin is able to absorb onto the surface of raw wastewater sludge flocs and during the biological treatment of wastewater it can be desorbed into the liquid phase. All analyses were conducted in filtered wastewater, therefore erythromycin concentration in the raw wastewater as the removal level could not be calculated. The highest removal was obtained for $\mathrm{N}$-acetylosulfamethoxazole (94 and 99\% for winter and summer, respectively), while trimethoprim was removed at the lowest level ( 8 and $22 \%$ for winter and summer, respectively). The results of the HPLC analysis are shown in Table 3.

\section{Enumeration of antibiotic resistant bacteria in activated sludge}

Traditional microbiological plating used for bacterial enumeration is not precise but it is useful for rough calculation of bacterial number changes during the experiment. The total number of bacteria during the year was changing from $12 \times 10^{9} \mathrm{~mL}^{-1}$ in summer to $42 \times 10^{9} \mathrm{~mL}^{-1}$ in winter (Figure 1a). The increase of bacterial number was observed in winter-spring season. Similar tendency was observed in case of erythromycin resistant bacteria, with the highest number in winter. The number of bacteria resistant towards sulfamethoxazole/trimethoprim was also the lowest in the summer, but the range of changes in case of sulfamethoxazole/trimethoprim resistant bacteria was less drastic during autumn - spring season (Figure 1b).

\section{Gram staining and MIC values of isolated antibiotic resistant strains}

The bacterial isolates resistant towards the antibiotics used in the experiment were obtained from activated sludge in Zabrze WWTP underwent Gram staining. In case of erythromycin resistant bacteria (Table 4) most of the isolates were Gram-negative. Only three strains (E1, E5 and E8) were identified as Gram-positive. Seven isolates presented very high MIC values
(>1024 $\mu \mathrm{g} \mathrm{mL}^{-1}$ ), while MIC values only for two strains were lower: for E3 was $256 \mu \mathrm{g} \mathrm{mL}^{-1}$ and for E7 was $512 \mu \mathrm{g} \mathrm{mL}^{-1}$.

Sulfamethoxazole/trimethoprim resistant bacteria isolated from activated sludge in Zabrze WWTP presented very high MIC values (all strains MIC values were above $>1024 \mu \mathrm{g}$ $\mathrm{mL}^{-1}$ ). Eight out of nine isolated were Gram-negative (Table 4).

PCR-based detection of antibiotic resistance genes and total biodiversity of the community analysis

The antibiotic resistance genes (emr, mef, sul1, sul2, sul3, dhfrAl, dhfrA14) can be detected in activated sludge as well as in pure strains using PCR amplification. Such a procedure enabled the resistance genes to be identified both in isolated strains known to be resistant to a particular antibiotic and in the activated sludge samples from which the pure strains were obtained. The PCR amplicons were separated electrophoretically and visualized under UV. Optimized PCR was performed twice, with comparable result.

Figure 2a presents PCR products obtained for erm gene and Figure $2 \mathrm{~b}$ for mef gene amplified in the erythromycin resistant strains E1-E9 and activated sludge sample. Table 4 (part A) presents the comparison of erm and mef genes presence in the erythromycin resistant strains E1-E9 and activated sludge sample.

The Figures $3 \mathrm{a}$ and $3 \mathrm{~b}$ respectively present the results of $d h f r A 1$ and $d h f r A 14$ genes amplification in bacterial resistant strains B1-B9 and in the activated sludge sample. The results for sul1 andsul2 genes PCR amplification for bacterial resistant strains B1-B9 and in activated sludge sample are shown in the Figures $4 \mathrm{c}$ and $4 \mathrm{~d}$, respectively. No sul3 gene was detected in this study. The comparison of sul and $d h f r$ genes presence in sulfamethoxazole/trimethoprim resistant bacterial strains and in the activated sludge from which these strains were isolated is presented in Table 4 (part B).

The PCR products of a $16 \mathrm{~S}$ rRNA gene fragment (length ca. $180 \mathrm{bp}$ ) obtained using 338F-GC and 518R primers were separated in polyacrylamide gel with 30-60\% denaturant gradient. The result was visualized in UV light (Figure 4a) and on the basis of densitometric analysis Shannon diversity index was calculated (Figure 4b). 
Table 3. The concentration and the removal percentage of selected antimicrobial agents in winter $\left(\mathrm{T}=10^{\circ} \mathrm{C}\right)$ and summer $\left(\mathrm{T}=20^{\circ} \mathrm{C}\right)$ at WWTP in Zabrze

\begin{tabular}{|c|c|c|c|c|}
\hline \multirow{2}{*}{ Antimicrobial agent } & Temperature & $\begin{array}{c}\text { Concentration } \\
\text { in the raw wastewater } \\
\text { [ng L-1] }\end{array}$ & $\begin{array}{c}\text { Concentration } \\
\text { in the treated wastewater } \\
\text { [ng L-1] }\end{array}$ & Removal [\%] \\
\hline \multirow{2}{*}{ sulfamethoxazole } & $T=10^{\circ} \mathrm{C}$ & $1745 \pm 253$ & $1003 \pm 146$ & 43 \\
\cline { 2 - 5 } $\begin{array}{c}\text { N-acetylo- } \\
\text { sulfamethoxazole }\end{array}$ & $T=20^{\circ} \mathrm{C}$ & $1778 \pm 274$ & $1226 \pm 205$ & 31 \\
\cline { 2 - 5 } trimethoprim & $T=10^{\circ} \mathrm{C}$ & $3349 \pm 719$ & $196 \pm 47$ & 94 \\
\cline { 2 - 5 } & $T=20^{\circ} \mathrm{C}$ & $2933 \pm 429$ & $39 \pm 18$ & 89 \\
\hline \multirow{2}{*}{ erythromycin } & $T=10^{\circ} \mathrm{C}$ & $400 \pm 22$ & $369 \pm 29$ & 22 \\
\cline { 2 - 5 } & $T=20^{\circ} \mathrm{C}$ & $364 \pm 60$ & $16 \pm 2$ & n.r. \\
\hline
\end{tabular}

n.d. - not detected

n.r. - no removal

a)

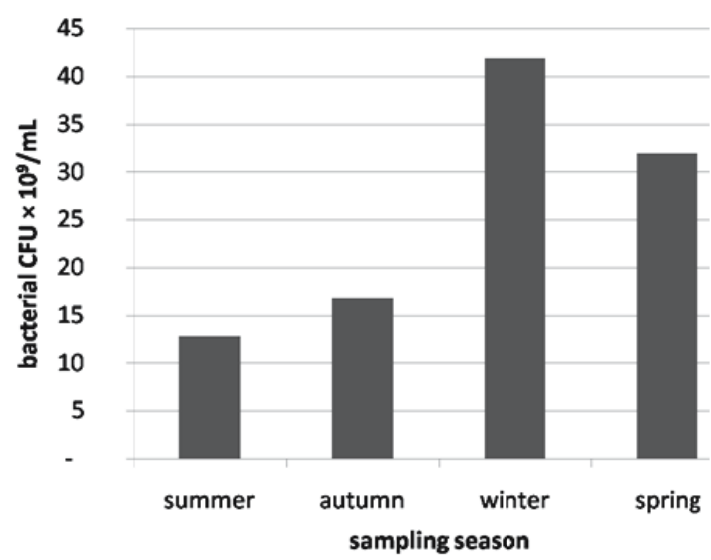

b)

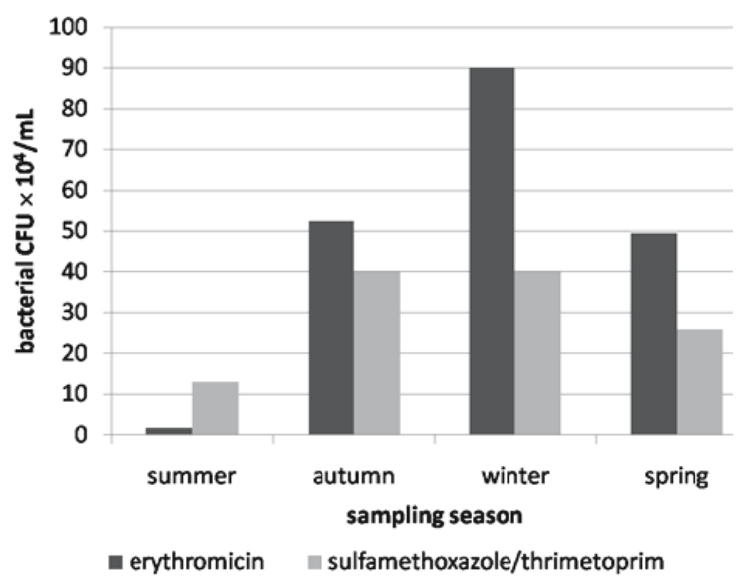

Fig. 1. Bacteria enumeration in activated sludge, performed with a plating method on Mueller-Hinton medium for four sampling seasons; a) total bacterial number; b) the number of erythromycin and sulfamethoxazole/trimethoprim resistant bacteria

Table 4. Gram staining and MIC value results erythromycin and sulfamethoxazole/trimethoprim resistant bacteria isolated from Zabrze WWTP activated sludge with the comparison of erm and mef genes presence in the erythromycin resistant strains E1-E9 and activated sludge (AS) sample (part A) and sul and $d h f r$ genes presence in the sulfamethoxazole/trimethoprim resistant strains B1-B9 and activated sludge (AS) sample (part B)

\begin{tabular}{|c|c|c|c|c|c|c|c|c|c|c|}
\hline \multicolumn{11}{|c|}{ PART A } \\
\hline Strain & E1 & E2 & E3 & E4 & E5 & E6 & E7 & E8 & E9 & AS \\
\hline Erm gene presence & + & + & - & + & + & + & - & + & + & + \\
\hline Mef gene presence & + & - & - & + & - & - & - & - & - & + \\
\hline Gram staining & + & - & - & - & + & & & & & $x$ \\
\hline MIC [ $\left.\mu \mathrm{g} \mathrm{mL}^{-1}\right]$ & $>1024$ & $>1024$ & 256 & $>1024$ & $>1024$ & $>1024$ & 512 & $>1024$ & $>1024$ & $x$ \\
\hline \multicolumn{11}{|c|}{ PART B } \\
\hline Strain & B1 & B2 & B3 & B4 & B5 & B6 & B7 & B8 & B9 & AS \\
\hline dhfrA1 resistance gene & - & - & + & - & + & - & - & - & + & + \\
\hline dhfrA14 resistance gene & - & - & - & - & + & - & - & + & + & + \\
\hline sul1 resistance gene & + & + & + & + & + & + & - & - & + & + \\
\hline sul2 resistance gene & - & - & + & + & + & - & - & - & + & + \\
\hline sul3 resistance gene & - & - & - & - & - & - & - & - & - & - \\
\hline Gram staining & - & - & - & - & - & - & + & - & - & $x$ \\
\hline MIC [ $\left.\mu \mathrm{g} \mathrm{mL}^{-1}\right]$ & $>1024$ & $>1024$ & $>1024$ & $>1024$ & $>1024$ & $>1024$ & $>1024$ & $>1024$ & $>1024$ & $x$ \\
\hline
\end{tabular}


a)

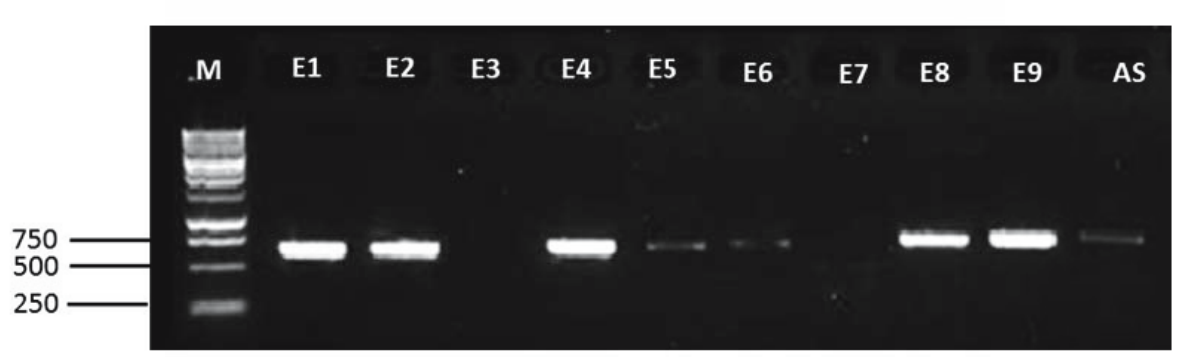

b)

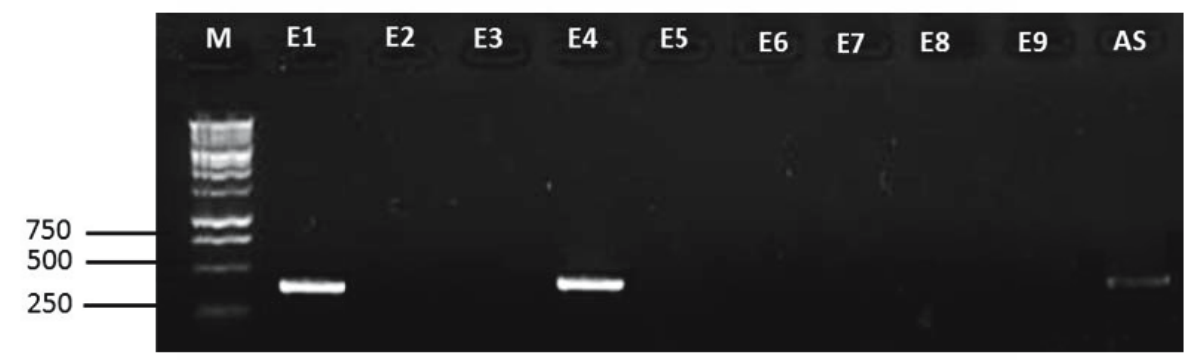

Fig. 2. PCR products obtained for (a) erm gene for the erythromycin resistant strains E1-E9 and activated sludge sample (AS);

(b) mef gene for the erythromycin resistant strains E1-E9 and activated sludge sample(AS); M - $1 \mathrm{~kb}$ ladder (Promega)
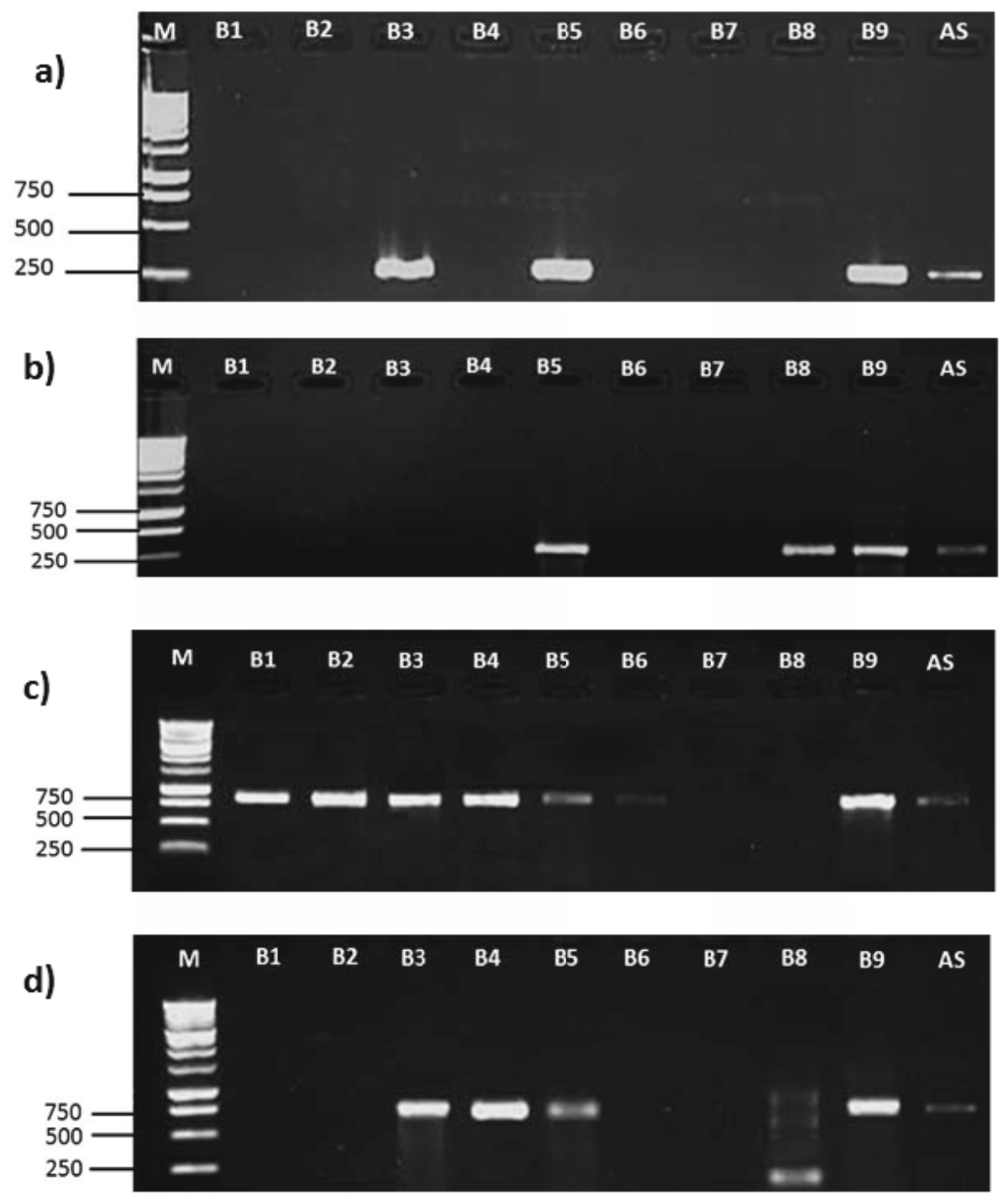

Fig. 3. PCR products obtained for: (a) dhfrA1 genes for the trimethoprim resistant strains B1-B9 and activated sludge sample (AS); (b) dhfrA14 genes for trimethoprim resistant strains B1-B9 and activated sludge sample (AS); (c) sul1 genes for sulfamethoxazole resistant strains B1-B9 and activated sludge sample(AS); (d) sul2 genes for sulfamethoxazole resistant strains B1-B9 and activa ted sludge sample(AS); M-1 kb ladder (Promega) 
a)

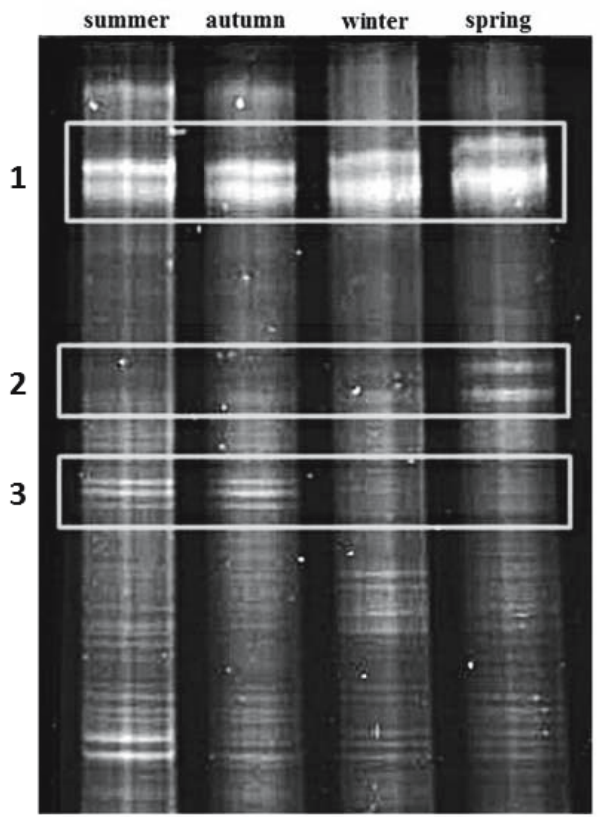

b)

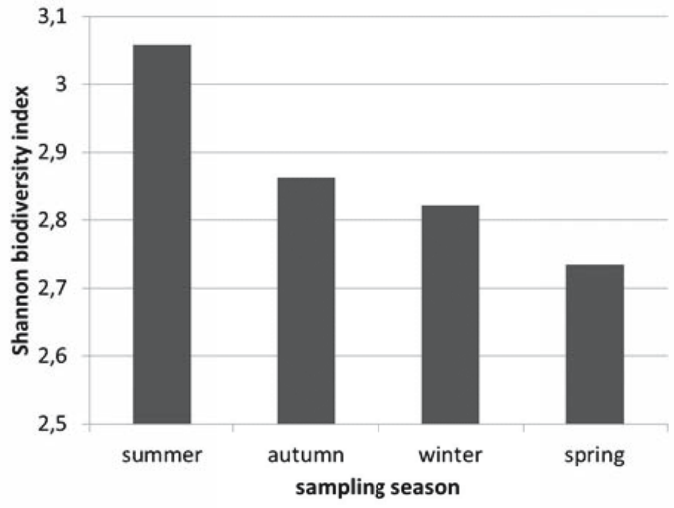

Fig. 4. (a) DGGE fingerprints obtained for activated sludge samples collected in summer, autumn, winter and spring season; PCR fragment length ca. 180 bp was separated in polyacrylamide gel with 30-60\% denaturant (frame 1 - genotypes present during total length of the experiment; frame 2 - genotyped appearing gradually; frame 3 - genotypes disappearing gradually);

(b) Shannon diversity index changeability calculated on the basis of densitometric analysis of DGGE picture for activated sludge samples collected in summer, autumn, winter and spring season

\section{Discussion}

The natural antibiotic substances have been used for ages. Bacteria, the antibiotic target, are able to gain resistance against particular antibiotic substances by the exchange of their genetic material in horizontal gene transfer (HGT). That is why the research to estimate the level, cause and range of antibiotic resistance in the environment is very important. Activated sludge in biological WWTPs is an excellent source for resistance genes, as well as a very good experimental biocenosis for resistance transfer analysis. In this experiment we try to correlate the levels of three antimicrobial compounds: erythromycin, sulfamethoxazole and trimethoprim, measured in communal WWTP in Zabrze, Poland with the occurrence of these antibiotics resistance genes in activated sludge analyzed with PCR. To evaluate this tool for the resistance monitoring in the environment we isolated erythromycin and sulfamethoxazole/trimethoprim resistant bacterial strains (nine each) from an activated sludge, to confirm the presence of these genes, both in pure strains and the activated sludge samples. In order to observe the changeability of antibiotic resistant bacteria level in activated sludge during the year, plating analysis was performed. The activated sludge samples collected in four seasons underwent PCR-DGGE analysis to present the genetic structure and changeability of activated sludge biocenosis.

According to ESAC (European Surveillance of Antimicrobial Consumption) in Poland in 2008 macrolides (together with lincosamides and streptogramidins it was $17.7 \%$ of total antibiotics consumption) were second the most popular group of antibiotics used in bacterial diseases treatment. Erythromycin was not detected in raw wastewater while in treated wastewater its concentration was not higher than $20 \mathrm{ng} \mathrm{L}^{-1}$ (Table 3). It could be explained that this antibiotic is present in the wastewater as its derivatives converted to erythromycin in WWTP conditions. Additionally, it can be adsorbed on suspended solids in the sewage and all the analyses were performed on filtrated wastewater, so the tests could give lowered levels of erythromycin concentration. No analyses of erythromycin derivatives were performed. It was also mentioned in the literature (Goebel et al. 2004) that erythromycin can easily convert into erythromycin $-\mathrm{H}_{2} \mathrm{O}$ form during sample preparation. This form of the antibiotic was also not analyzed in the experiment.

Sulfamethoxazole is one of the most popular sulphonamides in Poland. Its concentrations were comparable in both summer and winter season. The results obtained in the experiment suggests that this substance in better removed in winter $(43 \%)$, than in summer (31\%) (Table 3$)$. According to the bibliographic data (Goebel et al. 2004) sulfamethoxazole should be balanced together with its main derivative - N-acetylo-sulfamethoxazole, because in biological WWTPs the conversion back to sulfamethoxazole is often observed, regardless of the temperature. Thus the level of sulfamethoxazole removal together with its metabolite is at a comparable level in both experimental seasons. N-acetylo-sulfamethoxazole was the substance with the highest concentration in raw wastewater $(3349 \pm 719$ in winter and $2933 \pm 429 \mathrm{ng} \mathrm{L}^{-1}$ in summer). Trimethoprim used together with sulfamethoxazole was present in raw wastewater in lower 
concentration $\left(400 \pm 22\right.$ and $364 \pm 60 \mathrm{ng} \mathrm{L}^{-1}$, respectively in winter and summer). Trimethoprim was practically non removable $(8 \%)$ in winter, while in summer its removal was estimated to be ca. $22 \%$.

The total number of bacteria during the year was changing with the increase of bacterial number in winter-spring season (Figure 1a). Probably such a situation was observed because the biomass in the bioreactor was higher in order to maintain the effectiveness of wastewater treatment process in the lower temperatures. The same tendency was observed in case of erythromycin resistant bacteria, with the highest number in winter. The increase of the number of resistant bacteria could be caused by the higher usage of this antibiotic to treat bacteria diseases (Figure 1b), because as it was previously stated, the exposition to the drug can cause the increase of bacterial resistance (Silva et al. 2006, Soufi et al. 2010). Because erythromycin is known to possess wider bactericidal spectrum and it is used more often than sulfamethoxazole/trimethoprim, it is possible that its usage increased during winter. During this season the morbidity is higher and it caused the increase of resistant bacteria number in activated sludge. These results cannot be confirmed with HPLC results of erythromycin concentration in raw wastewater directed to the activated sludge tank because as mentioned earlier, samples preparation causes problems with analysis.

The number of bacteria resistant towards sulfamethoxazole/trimethoprim was also the lowest in the summer (Figure 1b), but the changeability range of sulfamethoxazole/trimethoprim resistant bacteria number was less drastic during autumn-spring season. Such a situation can be explained by sparser usage of these substances in health care in Poland. These drugs are more often used for urinary tracts than for respiratory tracts problems treatment and these health problems are seasonally variable. It should be also mentioned that trimethoprim removal during winter is lower, so bacteria are exposed to its higher dosages in WWTP. Resistance genes acquisition can be caused by longer exposition.

These data can be partially confirmed by DGGE results. As it can be seen in Figure 4a, some of the genotypes appear in winter - spring time, while more disappear. The total biodiversity decreases in winter - spring period and it could be suspected that the resistant bacteria are the genotypes constantly present and appearing in the fingerprint pattern. Biodiversity was decreasing from summer to spring, which suggests that the temperature was the most important factor for bacterial number changeability with higher multiplication in the higher temperatures during summer (Figure 4b). Interestingly, the biodiversity was decreasing but in the same time the number of bacteria estimated with plating method was increasing (Figure 1a). It is possible that only a few genotypes of bacteria were capable of multiplying during winter-spring season. AT-rich genotypes are present in DGGE patterns regardless to the sampling season (Figure 4a, Frame 1), while GC-rich genotypes number is changing (Figure 4a, Frame 2 and 3 ). It could be possible that GC-rich genotypes belong to resistant bacteria but this hypothesis requires further research.

Most of the activated sludge bacteria are Gram-negative (Forster et al. 2002). As it was suspected erythromycin resistant strains isolated in the experiment were mainly Gram-negative (Table 4). Only three strains (E1, E5, E8) were Gram-positive. Gram-negative bacteria possess an additional outer membrane impermeable towards a large number of toxic compounds which make them resistant towards harmful substances present in the environment. MIC values of the isolated erythromycin resistant strains are high. For seven of nine isolates minimal inhibitory concentration of the antibiotic is higher than $1024 \mu \mathrm{g} \mathrm{mL}^{-1}$. Only strains E3 and E7 presented lower resistance, their MIC values are 256 and $512 \mu \mathrm{g} \mathrm{mL}^{-1}$, respectively. According to the previous research (Schönberg-Norio et al. 2006) MIC higher than $1024 \mu \mathrm{g} \mathrm{mL}^{-1}$ characterizes clinical isolates. Activated sludge bacteria, as the clinical isolates, are in constant contact with the antibiotics which can be the cause of resistance development (Szczepanowski et al. 2004).

Seven isolates-E1, E2, E4, E5, E6, E8 and E9-possess erm $\mathrm{B}$ gene only (Figure 2, Table 4). In activated sludge both genes $-m e f$ and erm are present. According to the data obtained it could be stated that the main erythromycin resistance mechanism is enzymatic, posttranslational modification of $23 \mathrm{~S}$ rRNA, being the target for this antibiotic as the effect of ermB encoded N-methylotransferase activity. These results confirm previous bibliographic data suggesting that this mechanism is the most frequent erythromycin-resistance mechanism (Artur et al. 1990). Erm genes are located mostly on plasmids, so probably they spread among activated sludge bacteria in HGT.

Mef genes, responsible for active antibiotic removal from the bacterial cell, are present only in two strains, Gram-positive E1 and Gram-negative E4 (Figure 2, Table 4). These elements are located in bacterial chromosome, so that could be the explanation of its rarer occurrence. Nonetheless, the resistance transfer is possible and it was previously stated that these genes can be transferred from Gram-positive cocci to Gram-negative bacteria within transposons (Brisson-Nöel et al. 1988).

Strains E1 and E4 possess not only mef but also ermB genes. Probably their resistance is caused by both mechanisms. Such a combination of resistance genes was observed previously (Bley et al. 2011) and these strains presented higher resistance against erythromycin than strains possessing two genes separately.

Regardless of the erythromycin resistance revealed with plating method, strains E3 and E7 possessed none of the two resistance genes. It suggests that their erythromycin resistance is caused by some other genes, such as: ere, $m s r$, mph or other erm (except ermB) (Sutcliffe et al. 1996). In case of Gram-negative bacteria (such as Escherichia coli) it is possible that the resistance is based on enzymatic modification of antibiotic by ere coded esterases (Sutcliffe et al. 1996). PCR amplification of mef and ermB gave convergent results with MIC values. Strains with ermB gene present higher MIC (above $1024 \mu \mathrm{g} \mathrm{mL}^{-1}$ ), while the MIC values for other strains without ermB (E3 and E7) are lower. As it was previously stated, erm encoded resistance is linked with MIC values higher than these presented by strains possessing mph or mef encoded resistance (Martin et al. 2001, Nguyen et al. 2009). It could be suspected that the $23 \mathrm{~S}$ rRNA methylation is much more effective as an erythromycin resistance mechanism than the mechanism presented by strains E3 and E7. Nonetheless, the resistance paths for these isolates should be investigated.

Among nine sufamethoxazole/trimethoprim isolates only one strain was Gram-positive. MIC values pointed that all the strains were highly resistant to sulfamethoxazole/ trimethoprim (MIC > $1024 \mu \mathrm{g} \mathrm{mL}^{-1}$ ) (Table 4). In case of $d h f r / s u l$ 
genes combination it is justified, but in case of strain B7, which does not possess any of the investigated genetic determinant, such high resistance can be caused by chromosomal mechanisms of the resistance (Huovinen et al. 1995).

All strains, as well as the activated sludge samples, underwent PCR amplification with $d h f r A 1$ and $d h f r A 14$ primers (flanking the most commonly present trimethoprim resistance genes) and sul1, sul 2 and sul3 primers (targeting sulfamethoxazole resistance genes). Such primer sets were chosen on the basis of the previous research. It has been previously stated (Brolund et al. 2010) that $d h f r$ genes were spread among $E$. coli $(96 \%$ of the isolates) and Klebsiella pneumoniae strains ( $68 \%$ of the isolates, with the most often appearing $\operatorname{dhfrAl}$ gene). For $E$. coli second the most often appearing resistance gene was $d h f r A 14$. Also, it has been reported previously (Dworniczek et al. 2007) that the $d h f_{r} A l$ gene was the most commonly present in clinical $E$. coli strains. The most common trimethoprim resistance gene for Acinetobacter spp. and Campylobacter spp. was dhfrA1. Both genes: dhfrAl and $\operatorname{dhfrA14}$ were present in strains B5 and B9. But in five strains none of the $d h f r$ genes studied was present. According to the literature (Brolund et al. 2010) there are over 30 types of $d h f r$ genes, so there is a high probability that these strains possess one of the other trimethoprim resistance coding genes.

The amplification of sull, sul2 and sul3 genes revealed (Figure 3) that sull was present in the activated sludge sample and all analyzed strains except B7 and B8. In case of sul2, positive amplification was obtained for four strains: B3, B4, B5, B9 and the activated sludge sample. No sul3 gene amplification was obtained. In this experiment sull seems to be more frequent among the activated sludge isolates than sul2. These results are confirmed by previous works. The research (Toleman et al. 2007) performed on Stenotrophomonas maltophilia and in that case 17/25 strains possessed sul1 gene. The further research (Hoa et al. 2008) confirmed that data. In the case of previous research (Sköld 2001, Perreten and Boerlin 2003) sul1 and sul2 appear with an equal frequency among Gram-negative clinical strains. The absence of sul3 in the investigated activated sludge and strains is not odd. This gene is rare, it is present only among $30 \%$ E. coli isolated in research performed in 2003 (Perreten and Boerlin 2003). For clinical isolates of $E$. coli only $3 \%$ of bacteria possessed sul3, and in wastewater analysis the frequency of sul3 presence was ca. 14\% (Grape et al. 2003). The coexistence of sull and sul2 was stated for strains B3, B4, B5, B9 and activated sludge samples as it has been previously stated (Hoek et al. 2005). For strains B7 and B8 no sul was present. Due to the fact that sul genes are the only known sulfamethoxzole resistance genes, it could be suspected that for these strains, their resistance is caused by DHPS (enzyme) or PABA (substrate - para-aminobenzoic acid) overproduction. For B5 and B9 all investigated genetic determinants of the analyzed resistance except sul3 (absent in all cases) were present.

It was stated that there is over 140 already investigated plasmids carrying antibiotic and other toxic compounds resistance genes (Rahube and Yost 2010), so it is essential to monitor permanently their presence in WWTPs. The possibility that these genetic elements can be directed to water tracts outside WWTPs has been found to be a serious public health risk. In this experiment it was stated that the PCR-based method can be useful for erythromycin and sulfamethoxazole/trimethoprim resistance monitoring in WWTP activated sludge biocenosis. The results obtained for pure strains and activated sludge samples are convergent. Together with analytical method (HPLC), microbial plating and DGGE as a tool for biocenosis genetic structure studies, it is possible to estimate: the presence of resistance genes, the influence of antibiotic presence in wastewater to gaining resistance against them and the direction of microbial community changes linked with bacterial changeability.

\section{Acknowledgements}

This work was supported by Polish Ministry of Science and Higher Education, grant no. N N523 493134. The research were performed using the equipment purchased in the project "Silesian BIO-FARMA. The Center for Biotechnology, Bioengineering and Biocomputing", EFRR PO IG, 2007-2013.

\section{References}

Arthur, M., Molinas, C., Mabilat, C. \& Courvalin, P. (1990). Detection of erythromycin resistance by the polymerase chain reaction using primers in conserved regions of erm rRNA methylase genes, Antimicrobial Agents Chemotherapy, 34, pp. 2024-2026.

Bley, C., Linden, M. \& Reinert, R.R. (2011). Mef(A) is the predominant macrolide resistance determinant in Streptococcus pneumoniae and Streptococcus pyogenes, International Journal of Antimicrobial Agents, 37, pp. 425-431.

Brisson-Nöel, A., Arthur, M. \& Courvalin, P. (1988). Evidence for natural gene transfer from gram-positive cocci to Escherichia coli, Journal of Bacteriology, 170, pp. 1739-1745.

Brolund, A., Sundqvist, M., Kahlmeter, G. \& Grape, M. (2010). Molecular characterization of trimethoprim resistance in Escherichia coli and Klebsiella pneumonia during a two year intervention on trimethoprim use, PLoS ONE 16 e9233. DOI: 10.1371/journal.pone.0009233.

Dworniczek, E., Mróz, E., Skała, J., Przondo-Mordarska, A., Goj, A. \& Bortniczuk, M. (2007). Trimethoprim resistance in Escherichia coli strains isolated from patients with urinary tract infection in 1989-1994, Advances in Clinical and Experimental Medicine, 16, pp. 35-42.

Forster, S., Snape, J. R., Lappin-Scott, H. M. \& Porter, J. (2002). Simultaneous fluorescent Gram staining and activity assessment of activated sludge bacteria, Applied and Environmental Microbiology, 68, pp. 4772-4779.

Goebel, A., McArdell, C.S., Stuer, M.J. \& Giger, W. (2004). Trace determination of macrolide and sulfonamide antimicrobials, a human sulfonamide metabolite, and trimethoprim in wastewater using liquid chromatography coupled to electrospray tandem mass spectrometry, Analitycal Chemistry, 76, pp. 4756-4764.

Grape, M., Sundström, L. \& Kronvall, G. (2003) Sulphonamide resistance gene sul3 found in Escherichia coli isolates from human sources, Journal of Antimicrobial Chemotherapy, 52, pp. 1022-1024.

Hijosa-Valsero, M., Fink, G., Schluesener, M.P., Sidrach-Cardona, R., Martín-Villacorta, J., Ternes, T. \& Bécares, E. (2011). Removal of antibiotics from urban wastewater by constructed wetland optimization, Chemosphere, 83, pp. 713-719.

Hoa, P.T., Nonaka, L., Vie, P.H. \& Suzuki, S. (2008). Detection of the sul1, sul2, and sul3 genes in sulfonamide - resistant bacteria from wastewater and shrimp pond of North Vietnam, Science of the Total Environment, 405, pp. 377-384.

Hoek, A.H., Scholtens, I.M., Cloeckaert, A. \& Aarts, H.J. (2005) Detection of antibiotic resistance genes in different 
Salmonella serovars by oligonucleotide microarray analysis, Journal of Microbiological Methods, 62, pp. 13-23.

Huovinen, P. (2001). Resistance to trimethoprim - sulfamethoxazole, Clinical Infectious Diseases, 32, pp. 1608-1614.

Huovinen, P., Sundström, L., Swedberg, G. \& Sköld, O. (1995). Trimethoprim and sulfonamide resistance, Antimicrobial Agents Chemotherapy, 39, pp. 279-289.

Kümmerer, K. (2009). Antibiotics in the aquatic environment, Chemosphere, 75, pp. 417-434.

Martin, S., Garvin, C.G., McBurney, C.R. \& Sahloff, E.G. (2001). The activity of 14-hydroxy clarithromycin, alone and in combination with clarithromycin, against penicillin - and erythromycin - resistant Streptococcus pneumonia, Journal of Antimicrobial Chemotherapy, 47, pp. 581-587.

Matsuoka, M., Inoue, M., Endo, Y. \& Nakajima, Y. (2003). Characteristic expression of three genes, $\operatorname{msr}(\mathrm{A}), \operatorname{mph}(\mathrm{C})$ and $\operatorname{erm}(\mathrm{Y})$ that confer resistance to macrolide antibiotics on Staphylococcus aureus, FEMS Microbiology Letters, 220, pp. 287-293.

Muyzer, G., De Waal, E.C. \& Uitierlnden, A.G. (1993). Profiling of complex microbial populations by denaturing gradient gel electrophoresis analysis of polymerase chain reaction-amplified genes coding for 16S rRNA, Applied and Environmental Microbiology, 59, pp. 695-700.

Nguyen, M.C.P., Woerther, P.-L., Bouvet, M., Andremont, A., Leclercq, R. \& Canu, A. (2009). Escherichia coli as reservoir for macrolide resistance genes, Emerging Infectious Diseases, 15, pp. 1648-1651.

Oliver, J.D. (2010). Recent findings on the viable but nonculturable state in pathogenic bacteria, FEMS Microbiology Reviews, 34, pp. 415-425.

Perreten, V. \& Boerlin, P.A. (2003). New sulfonamide resistance gene (sul3) in Escherichia coli is widespread in the pig population of Switzerland, Antimicrobial Agents and Chemotherapy, 47, pp. 1169-1172.

Rahube, T.O. \& Yost, C.K. (2010) Antibiotic resistance plasmids in wastewater treatment plants and their possible dissemination into the environment, African Journal of Biotechnology. 54, pp. 9183-9190.

Schluesener, M.P., Spiteller, M. \& Bester, K. (2003). Determination of antibiotics from soil by pressurized liquid extraction and liquid chromatography-tandem mass spectrometry, Journal of Chromatography, 1003, pp. 21-28.
Schönberg-Norio, D., Hänninen, M.-L., Katila, M.-L., Kaukoranta, S.-S., Koskela, M., Eerola, E., Uksila, J., Pajarre, S. \& Rautelin, H. (2006). Activities of telithromycin, erythromycin, fluoroquinolones, and doxycycline against Campylobacter strains isolated from Finnish subjects, Antimicrobial Agents Chemotherapy, 50, pp. 1086-1088.

Silva, J., Castillo, G., Callejas, L., López, H. \& Olmos, J. (2006). Frequency of transferable multiple antibiotic resistance among coliform bacteria isolated from a treated sewage effluent in Antofagasta, Chile, Electronic Journal of Biotechnology, 5, pp. 533-540.

Sköld, O. (2001). Resistance to trimethoprim and sulfonamides, Veterinary Research, 32, pp. 261-273.

Soufi, L., Sáenz, Y., Vinué, L., Abbassi, M.S., Ruiz, E., Zarazaga, M., Hassen, A.B., Hammami, S. \& Torres, C. (2010). Escherichia coli of poultry food origin as reservoir of sulphonamide resistance genes and integrons, International Journal of Food Microbiology, 144, pp. 497-502.

Sutcliffe, J., Grebe, T., Tait-Kamradt, A. \& Wondrack, L. (1996). Detection of erythromycin-resistant determinants by PCR, Antimicrobial Agents Chemotherapy, 40, pp. 2562-2566.

Szczepanowski, R., Krahn, I., Linke, B., Goesmann, A., Pühler, A. \& Schlüter, A. (2004). Antibiotic multiresistance plasmid pRSB101 isolated from a wastewater treatment plant is related to plasmids residing in phytopathogenic bacteria and carries eight different resistance determinants including a multidrug transport system, Microbiology, 150, pp. 3613-3630.

Toleman, M.A., Bennett, P.M., Bennett, D.M., Jones, R.N. \& Walsh, T.R. (2007). Global emergence of trimethoprim/ sulfamethoxazole resistance in Stenotrophomonas maltophilia mediated by acquisition of sul genes, Emerging Infectious Diseases, 13, pp. 559-565.

Weisblum, B. (1995). Erythromycin resistance by ribosome modification, Antimicrobial Agents and Chemiotherapy, 39, pp. 577-585.

Wise, R. (2002). Antimicrobial resistance: Priorities for action, Journal of Antimicrobial Chemotherapy, 49, pp. 585-586.

Ziembińska, A., Ciesielski, S. \& Miksch, K. (2009). Ammonia oxidizing bacteria community in activated sludge monitored by denaturing gradient gel electrophoresis (DGGE), Journal of General and Applied Microbiology, 55, pp. 373-380.

\title{
Wykrywanie genów oporności na antybiotyki w oczyszczalni ścieków - podejście klasyczne i biologii molekularnej
}

\begin{abstract}
Streszczenie: Antybiotyki to grupa związków potencjalnie szkodliwych dla środowiska. Odgrywają one rolę w procesach transferu antybiotykooporności pomiędzy patogenami i bakteriami niechorobotwórczymi. Wykorzystując metodę wysokosprawnej chromatografii cieczowej (HPLC) wykazano obecność erytromycyny, sulfametoksazolu i trimetoprimu w miejskiej oczyszczalni ścieków w następujących stężeniach: dla erytromycyny $<20 \mathrm{ng} \mathrm{L}^{-1}$, N-acetylo-sulfametoksazolu $3349 \pm 719$ i $2933 \pm 429 \mathrm{ng} \mathrm{L}^{-1}$, a trimetoprimu $400 \pm 22$ i $364 \pm 60 \mathrm{ng} \mathrm{L}^{-1}$, odpowiednio: zimą i latem. Ponieważ antybiotykooporność bakteryjna może być stymulowana obecnością antybiotyków w środowisku, istnieje możliwość pojawienia się wielu szlaków opornościowych u bakterii narażonych na działanie tych związków. Dlatego też podjęto próbę detekcji wybranych genów oporności na badane chemioterapeutyki metodą łańcuchowej reakcji polimerazy (PCR). Obecność elementów genetycznych badano zarówno w szczepach bakteryjnych, u których udowodniono oporność na badany związek bakteriobójczy, jak i w próbce osadu czynnego, z którego te bakterie izolowano. Do badań wybrano najczęściej występujące geny oporności: dla erytromycyny erm i mef, dla sulfametoksazolu: sull, sul2, sul3, a dla trimetoprimu $d h f r A 1$ i dhfr 14 . Wykazano, że wartość minimalnego stężenia inhibitującego (MIC), nie koresponduje z obecnością większej liczby mechanizmów oporności. Większość szczepów opornych wykazywała tylko jeden z badanych mechanizmów oporności na antybiotyk niezależnie od wartości MIC. Potwierdzono również możliwość monitorowania obecności genów oporności na antybiotyki metodą PCR bezpośrednio w osadzie czynnym. Ze względu na ograniczona liczbę izolatów użytych w tym eksperymencie wyniki uzyskane w pracy powinny być traktowane jako wstęp do dalszych badań.
\end{abstract}

